\title{
PERILAKU SEKSUAL BERISIKO PENULARAN HIV PADA TENAGA KERJA BONGKAR MUAT DI PELABUHAN KALIMAS SURABAYA
}

\author{
HIV Transmission Through Risky Sexual Behaviors By The Dockworkers At Kalimas \\ Dock Surabaya
}

\author{
Kurnia Margawati, Arief Hargono \\ Departemen Epidemiologi \\ Fakultas Kesehatan Masyarakat, Universitas Airlangga Surabaya \\ Email: scnsqn@gmail.com
}

\begin{abstract}
HIV is a disease attacking immune system with sexual behaviors as one of its transmission media, especially for those categorized as high-risk groups. The result of Integrated Survey on Biological Behaviors (STBP) defines the TKBM (informal dockworkers) as one of these high-risk groups. The aim of this study is to identify the correlations between characteristics, knowledge, and behaviors of the dockworker on the transmission of HIV through risky sexual behaviors at Kalimas Dock, Surabaya. This study was conducted based on Cross sectional design and quantitative approach. Interview on the 52 respondents of this study was carried out by using questionnaire. This research used Simple random sampling method to chose responden on dockworkers at PT " $X$ ”, located at Kalimas Dock, Surabaya. The analysis of the research used Chi Square analysis on the collected data with significance value $\alpha$ $<0.05$. The findings of this study show dockworkers coming home frequency $(p$-value $=0.026 ; P R=$ 2.13), knowledge $(p$-value $=0.013 ; P R=3.04)$, and attitude $(p$-value $=0.05, P R=2.05)$ correlate with transmission of HIV at Kalimas Dock. Meanwhile, other factors, such as educational background $(p$-value $=0.162)$, marital status ( $p$-value $=0.705)$, and access towards HIV transmission related counseling $(p$-value $=1)$ do not correlates. These findings imply several recommended that public health officers conduct counseling on preventing HIV transmission for dockworkers in order to improve their knowledge and attitude on HIV. PT " $X$ " should implement weekly working shift for the dockworkers so that the dockworkers could spend more time with their family.
\end{abstract}

Keywords: HIV, Sexual Behavior, Dockworkers

\begin{abstract}
Abstrak: HIV merupakan penyakit yang menyerang kekebalan tubuh dengan perilaku seksual sebagai salah satu sarana penularannya, terutama perilaku seksual pada kelompok risiko. TKBM (Tenaga Kerja Bongkar Muat) merupakan salah satu kelompok pria berisiko tinggi berdasarkan pendekatan pekerjaan menurut Survei Terpadu Biologis dan Perilaku (STBP). Penelitian ini dilakukan untuk mengetahui hubungan antara karakteristik, pengetahuan, dan sikap TKBM dengan perilaku seksual berisiko penularan HIV di Pelabuhan Kalimas Surabaya. Penelitian ini dilaksanakan dengan rancangan Cross sectional dengan menggunakan pendekatan kuantitatif. Wawancara dilakukan dengan menggunakan kuisioner pada 52 TKBM Cara pengambilan sampel dilakukan dengan menggunakan Simple random sampling dari PT. "X" di Pelabuhan Kalimas Surabaya. Analisis data yang digunakan adalah uji Chi square dengan derajat kemaknaan $\alpha<0,05$. Hasil menunjukkan ada hubungan antara frekuensi pulang kerumah (P-value 0,026; $\mathrm{PR}=2,13$ ), pengetahuan ( $\mathrm{P}$-Value 0,013: $\mathrm{PR}=3,04)$, dan sikap ( $\mathrm{P}$-value 0,005; $\mathrm{PR}=2,05$ ) dengan perilaku seksual berisiko penularan HIV di Pelabuhan Kalimas Surabaya. Sementara itu pendidikan (P-value 0,162), status perkawinan (P-Value 0,705), dan keterpaparan terhadap penyuluhan (P-Value 1) tidak berhubungan dengan variabel tersebut. Diharapkan untuk petugas kesehatan untuk memberikan penyuluhan tentang upaya preventif HIV pada TKBM. Sebagai upaya untuk meningkatkan pengetahuan dan sikap TKBM tentang HIV. Untuk PT. "X" di Pelabuhan Kalimas Surabaya dapat memberikan shift kerja perkelompok tiap minggunya, sehingga diharapkan TKBM memiliki waktu berkumpul bersama keluarganya.
\end{abstract}

Kata kunci: HIV, Perilaku Seksual, Tenaga Kerja Bongkar Muat

\section{PENDAHULUAN}

Human Immunodeficiency Virus atau HIV merupakan virus yang menginfeksi sel darah putih sehingga menyebabkan turunnya kekebalan tubuh. Hal ini menyebabkan tubuh tidak dapat melawan infeksi yang masuk ke dalam tubuh. Virus ini termasuk masuk ke dalam kategori retrovirus, dimana seseorang 
yang terinfeksi akan mengalami infeksi selama hidupnya. Orang yang terinfeksi HIV biasanya tidak memiliki gejala untuk jangka waktu yang lama, namun dapat menularkan kepada orang lain. (Permenkes RI No 51, 2013). HIV disebut retrovirus karena virus ini memiliki enzim reverse transcriptase sehingga mampu mengubah RNA virus menjadi DNA (Yulistiani dan Sumarno, 2013).

AIDS (Acquired Immuno Deficiency Syndrome) adalah sekumpulan penyakit yang ditimbul karena turunnya sistem kekebalan tubuh sehingga mudah terserang berbagai macam penyakit infeksi (Kementerian Kesehatan RI, 2014). AIDS merupakan syndrom akibat defisiensi immunitas seluler tanpa penyebab lain yang diketahui. Ditandai dengan adanya infeksi oportunistik. Hal tersebut disebabkan karena berkurangnya zat kekebalan tubuh yang prosesnya terjadi sekitar 5-10 tahun setelah tubuh terinfeksi HIV (Widoyono, 2011).

Penderita HIV diseluruh dunia pada tahun 2013 berjumlah 35 juta jiwa, dimana setiap tahunnya infeksi HIV selalu bertambah. Tahun 2013 jumlah kematian akibat AIDS sebesar 1,5 juta jiwa (Kementerian Kesehatan RI, 2014).

Perkembangan HIV di Indonesia cukup pesat, sejak ditemukannya kasus pertama pada tahun 1987 hingga bulan september 2014. Penderita HIV tersebar hampir diseluruh wilayah Indonesia, dengan jumlah 386 kasus (78\%) dari 498 Kota dan kabupaten dari seluruh propinsi di Indonesia. Penderita HIV di Indonesia diderita hampir setiap kelompok usia. Mayoritas usia 2549 tahun yaitu 16.421 penderita, dan usia 50 tahun 1.261 penderita. Penderita pada tahun 2014 banyak diderita oleh laki-laki lebih yaitu sebesar 13.280 penderita dan perempuan sebesar 9.589 penderita. Dengan faktor risiko didominasi oleh heteroseksual sebesar 8.922 penderita (Kementerian Kesehatan RI, 2014).

Jawa Timur merupakan salah satu provinsi dengan jumlah kasus HIV tertinggi kedua setelah DKI Jakarta. Hasil sero survey HIV di Jawa Timur yang dilakukan pada pekerja seks komersial di 10 kabupaten menunjukkan angka lebih dari 5\% secara konsis. Hal ini menunjukkan bahwa Jawa
Timur sudah masuk ke dalam tingkat epidemi HIV terkonsentrasi. (Dinas Kesehatan Provinsi Jawa Timur, 2014). Jumlah kasus HIV tertinggi di Jawa Timur berada di Kota Surabaya dengan jumlah penderita HIV sebesar 3.889 kasus, hal ini menjadikan Kota Surabaya menempati peringkat pertama dari 38 kabupaten/Kota di Jawa Timur (P2 Dinkesprov Jatim, 2015).

Peningkatan kasus HIV saat ini sangat menghawatirkan, terutama jika tidak ada perhatian dan kewaspadaan di masyarakat. Hal ini dapat mengancam kehidupan generasi penerus bangsa, membahayakan perkembangan sosial dan ekonomi serta keamanan negara. Serta dapat berpengaruh terhadap demografi dengan menurunnya harapan hidup. Sehingga menyebabkan kontribusi terhadap perekonomian dan perkembangan nasional semakin sedikit. Sedangkan dalam pelayanan kesehatan, membutuhkan perawatan yang lebih banyak dan dana yang besar. Di bidang sosial ekonomi dapat menyebabkan terganggunya produktivitas, sehingga dapat meningkatkan angka kemiskinan dan ketidakseimbangan ekonomi. Sedangkan dalam tatanan sosial akan terjadi stigma diskriminasi oleh masyarakat (Margawati, 2016).

Menurut data Survei Terpadu Biologis dan Perilaku (2011), kelompok populasi berisiko penularan HIV adalah wanita pekerja seks langsung maupun tidak langsung, penasun, waria, LSL, remaja dan pria berisiko diantaranya ojek motor, supir angkutan umum, Anak Buah Kapal, Tenaga Kerja Bongkar Muat (TKBM), dan Buruh.

Surabaya merupakan ibu Kota Provinsi Jawa Timur yang termasuk Kota metropolis dan strategis. Memiliki banyak pabrik, tempat hiburan, pusat perbelanjaan, Pelabuhan dan lain sebagainya. Pelabuhan merupakan sektor utama tempat persinggahan barang baik antar pulau ataupun antar negara. Mobilisasi kapal menjadi kebutuhan, terutama untuk perdagangan dan transportasi. Hal ini dapat menumbuhkan perekonomian negara dan dapat menambah devisa negara. Pelabuhan yang ada di Surabaya diantaranya adalah Pelabuhan Kalimas.

Pelabuhan Kalimas Surabaya berada di sebelah Timur Sungai Kalimas. Lokasi 


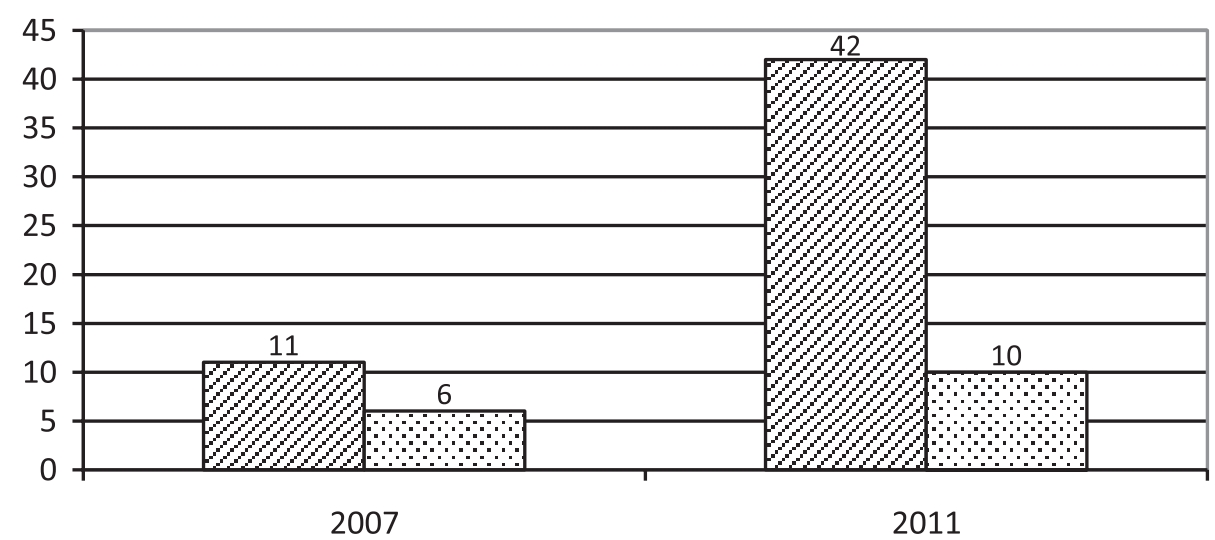

Q seks dengan WPS setahun terakhir $\square$ seks dengan pasangan kausal

Sumber: STBP 2011

Gambar 1. Perilaku Berisiko Seksual dalam Setahun Terakhir, Berdasarkan STBP Tahun 2007 dan 2011

Pelabuhan ini dekat dengan Pelabuhan Tanjung Perak Surabaya. Pelabuhan Kalimas merupakan salah satu Pelabuhan rakyat dan kapal lokal terbesar di Kota Surabaya. Hasil wawancara dengan kepala terminal Pelabuhan Kalimas Surabaya dalam Margawati (2016), Luas Terminal Kalimas $246.005 \mathrm{~m}^{2}$, dengan luas Dermaga Lokal 797 m dan Dermaga Pelra 1.420 m. Jumlah gedung yang dimiliki sebanyak 32 unit. Di Pelabuhan ini setiap harinya berlangsung aktivitas bongkar muat terutama kayu, tongkang dan perahu. Aktivitas bongkar muat dilakukan di siang dan malam hari.

TKBM atau lebih dikenal sebagai kuli angkut termasuk dalam bidang kerja informal. Pekerjaan ini tidak membutuhkan tingkat pendidikan yang tinggi dan keterampilan yang khusus. Upaya kesehatan juga jarang diberikan oleh para pengelolanya.

Para pekerja ini tidak hanya berasal dari Kota Surabaya. Namun ada yang berasal dari luar Kota Surabaya, bahkan ada yang berasal dari luar Pulau Jawa. Jarak rumah dan tempat bekerja yang jauh, menyebabkan para TKBM memiliki frekuensi meninggalkan rumah cukup lama. Hal ini menjadikan TKBM menjadi orang yang berisiko terhadap HIV berdasarkan pekerjaan menurut STBP 2011.

Data STBP pada kelompok berisiko tinggi di Indonesia pada tahun 2011, untuk prevalensi HIV pada pria pekerja Pelabuhan sebesar $0,3 \%$. Dengan pengetahuan yang komperhensif 3\%, melakukan hubungan seksual tanpa perlindungan dengan pasangan tidak tetap dalam satu tahun terakhir sebesar $83 \%$. Sedangkan penderita AIDS pada buruh kasar sebesar dari tahun 1987 sampai 2014 sebesar 2.169 (Dirjen P2PL, 2011).

Hasil STBP tahun 2007, dalam Depkes RI (2009), tingkat kesetiaan TKBM pada pasangan menurut perilaku abstinence, be faithful, condom (ABC) dalam satu tahun adalah TKBM yang puasa sex $2 \%$, setia pada pasangan $34 \%$, memakai kondom $20 \%$, dan yang melakukan seks berisiko $45 \%$. Data STBP tahun 2011 tingkat kesetiaan pria berisiko antara $32-56 \%$, dengan risiko tertular HIV sebesar 56\% (Dirjen P2PL, 2011).

Penelitian ini bertujuan untuk menganalisis adanya hubungan antara karakteristik responden yang terdiri dari tingkat pendidikan, status perkawinan, frekuensi pulang ke rumah, dan keterpaparan terhadap penyuluhan dengan perilaku seksual berisiko penularan HIV di PT. "X" di Pelabuahan Kalimas Surabaya. Serta untuk menganalisis adanya hubungan antara pengetahuan dan sikap responden dengan perilaku seksual berisiko penularan HIV di PT. "X” di Pelabuhan Kalimas Surabaya. 


\section{METODE}

Jenis penelitian yang digunakan dalam penelitian ini adalah observasional analitik. Peneliti hanya melakukan observasi pada objek tanpa memberikan perlakuan. Rancang bangun yang digunakan adalah Cross sectional, yaitu mengukur paparan dan penyakit secara simultan dalam satu sampel. Penelitian ini dilakukan pada saat atau waktu tertentu secara bersamaan terhadap populasi atau sampel.

Sampel penelitian ini diambil dari TKBM di PT. "X" di Pelabuhan Kalimas Surabaya berjumlah 52 responden. Dengan kriteria telah bekerja sebagai TKBM minimal 1 tahun dan bersedia menjadi responden. Teknik sampling yang digunakan adalah Simple random sampling, elemen populasi dilakukan sedemikian rupa sehingga setiap elemen memiliki kesempatan yang sama untuk dipilih sebagai sampel (Supranto, 2008). Penelitian ini dilakukan di PT. "X" di Pelabuhan Kalimas Surabaya, pada bulan Desember 2015 sampai Januari 2016.

Teknik pengumpulan data yang digunakan dalam penelitian ini adalah dengan menggunakan kuisioner. Sebelum dilakukan pengumpulan data, responden diberi penjelasan tentang pelaksanaan penelitian dan informed consent. Setelah mendapatkan ijin dan persetujuan responden, selanjutnya melakukan wawancara kepada responden dengan menggunakan alat bantu berupa kuisioner.

Pengolahan data dilakukan dengan cara editing data, coding, entry, dan cleaning. Analisis data merupakan analisis yang digunakan untuk menganalisis tiap variabel. Data dianalisis dengan menggunakan statistik diskriptif untuk mendapatkan tabulasi, dan menggunakan rumus penelitian yang dijelaskan dengan Chi square untuk melihat hubungan antar variabel. Hasil analisis dilaporkan dalam bentuk distribusi frekuensi dan persentase (\%) dari tiap variabel.

\section{HASIL}

Berikut ini adalah hasil dari penelitian yang dilakukan pada responden TKBM di PT. "X" di Pelabuhan Kalimas Surabaya. Berdasarkan Tabel 1, didapatkan bahwa sebagian besar responden memiliki tingkat pendidikan rendah sebanyak 51,9\%. Mayoritas responden berstatus menikah yaitu sebanyak $84,6 \%$. Frekuensi pulang ke rumah pada responden memiliki jumlah yang sama besar yaitu $<2 \mathrm{kali} /$ bulan sebesar $50 \%$ dan $\geq 2 \mathrm{kali} /$ bulan sebesar 50\%. hampir seluruh responden tidak pernah mendapatkan penyuluhan tentang HIV yaitu sebanyak 90,4\%. Sebagian besar responden memiliki pengetahuan kurang tentang HIV yaitu sebanyak $44,2 \%$ dan mayoritas memiliki sikap positif terhadap HIV yaitu sebanyak $65,4 \%$.

Untuk mengetahui faktor yang berhubungan dengan perilaku seksual berisiko penularan HIV pada TKBM di PT. "X" di Pelabuhan Kalimas Surabaya, menggunakan analisis bivariat yaitu uji Chi square dan Fisher's exact. Dan untuk melihat kemungkinan timbulnya perilaku yang berhubungan dengan faktor risiko, maka dilakukan penghitungan angka risiko relatif. Dalam penelitian Cross sectional menggunakan angka Prevalence Rasio (PR). Angka PR dihasilkan dari membandingkan

Tabel 1. Distribusi Frekuensi Responden Berdasarkan Variabel Independen Di PT. "X" Di Pelabuhan Kalimas Surabaya Tahun 2015

\begin{tabular}{lcc}
\hline \multirow{2}{*}{ Variabel Independen } & \multicolumn{2}{c}{ Responden } \\
\cline { 2 - 3 } & $\boldsymbol{F}$ & $\mathbf{\%}$ \\
\hline Pendidikan & & \\
Pendidikan rendah & 27 & 51,9 \\
Pendidikan tinggi & 25 & 48,1 \\
\hline Status perkawinan & & \\
Menikah & 44 & 84,6 \\
Lajang & 8 & 15,4 \\
\hline Frekuensi pulang ke rumah & & \\
- 2 kali/bulan & 26 & 50 \\
> kali/bulan & 26 & 50 \\
\hline Keterpaparan penyuluhan & & \\
Tidak pernah & 47 & 90,4 \\
Pernah & 5 & 9,6 \\
\hline Pengetahuan & & \\
Kurang Baik & 23 & 44,2 \\
Cukup baik & 14 & 26,9 \\
Baik & 15 & 28,8 \\
\hline Sikap & & \\
Negatif & 18 & 34,6 \\
Positif & 34 & 65,4 \\
\hline
\end{tabular}

Sumber: Data Primer, 2015 
prevalensi perilaku seksual berisiko penularan HIV pada kelompok yang berisiko dengan prevalensi perilaku seksual berisiko penularan HIV dengan kelompok yang tidak berisiko.

Hasil penelitian dari analisis bivariat berdasarkan Tabel 2, didapatkan hasil bahwa tidak ada hubungan yang signifikan antara tingkat pendidikan responden dengan perilaku seksual berisiko penularan HIV. Artinya pendidikan responden tidak mempengaruhi perilaku seksual berisiko penularan HIV di PT. "X" di Pelabuhan Kalimas Surabaya.

Tidak ada hubungan yang signifikan antara status pernikahan dengan perilaku seksual berisiko penularan HIV. Artinya status perkawinan responden tidak mempengaruhi perilaku seksual berisiko penularan HIV di PT. "X" di Pelabuhan Kalimas Surabaya.

Terdapat hubungan yang signifikan antara frekuensi pulang ke rumah dengan perilaku seksual berisiko penularan HIV. Artinya frekuensi pulang pada responden memiliki pengaruh terhadap perilaku seksual berisiko penularan HIV di PT. "X" di Pelabuhan Kalimas Surabaya. Dengan risiko berperilaku seksual berisiko penularan HIV pada responden yang frekuensi pulangnya $\leq 2$ kali perbulan 2,13 kali lebih besar dari responden yang frekuensi pulangnya $>2$ kali perbulan.

Tidak ada hubungan yang signifikan antara perilaku seksual berisiko penularan HIV dengan keterpaparan terhadap penyuluhan HIV. Artinya keterpaparan penyuluhan tentang HIV pada responden tidak mempengaruhi perilaku seksual berisiko penularan HIV di PT. "X" di Pelabuhan Kalimas Surabaya.

Terdapat hubungan yang signifikan antara pengetahuan dengan perilaku seksual berisiko penularan HIV. Artinya pengetahun responden tentang HIV mempengaruhi perilaku seksual berisiko penularan HIV di PT. "X" Pelabuhan Kalimas Surabaya. Dengan risiko berperilaku seksual berisiko penularan HIV pada responden yang memiliki pengetahuan rendah tentang HIV 2,28 kali lebih besar dari responden yang memiliki pengetahuan yang baik tentang HIV.

Ada hubungan yang signifikan antara sikap dengan perilaku seksual berisiko penularan HIV. Artinya sikap responden

Tabel 2. Hubungan Variabel Independen Dengan Perilaku Seksual Berisiko Penularan HIV Di PT. "X” Di Pelabuhan Kalimas Surabaya Tahun 2015

\begin{tabular}{|c|c|c|c|c|}
\hline \multirow{2}{*}{ Variabel Independen } & \multicolumn{2}{|c|}{ Perilaku Seksual Berisiko } & \multirow{2}{*}{ P-value } & \multirow{2}{*}{$\begin{array}{c}\text { PR } \\
95 \% \text { CI }\end{array}$} \\
\hline & Berisiko (\%) & Tidak berisiko (\%) & & \\
\hline \multicolumn{5}{|l|}{ Pendidikan } \\
\hline Pendidikan rendah & 59,3 & 40,7 & \multirow[t]{2}{*}{0,162} & 1,65 \\
\hline Pendidikan tinggi & 36,0 & 64,0 & & $(0,90-3,03)$ \\
\hline \multicolumn{5}{|l|}{ Status perkawinan } \\
\hline Menikah & 50,0 & 50,0 & \multirow[t]{2}{*}{0,705} & 1,33 \\
\hline Lajang & 37,7 & 62,5 & & $(0,52-3,42)$ \\
\hline \multicolumn{5}{|l|}{ Frekuensi pulang ke rumah } \\
\hline$\leq 2 \mathrm{kali} / \mathrm{bulan}$ & 65,4 & 34,6 & \multirow{2}{*}{0,026} & 2,13 \\
\hline$>2$ kali/bulan & 30,8 & 69,2 & & $(1,12-4,03)$ \\
\hline \multicolumn{5}{|l|}{ Keterpaparan penyuluhan } \\
\hline Tidak pernah & 48,9 & 51,1 & \multirow{2}{*}{1,000} & 1,22 \\
\hline Pernah & 40,0 & 60,0 & & $(0,40-3,72)$ \\
\hline \multicolumn{5}{|l|}{ Pengetahuan } \\
\hline Kurang baik & 60,9 & 39,1 & \multirow[t]{2}{*}{0,013} & 3,04 \\
\hline Baik & 20,0 & 80,0 & & $(1,05-8,82)$ \\
\hline \multicolumn{5}{|l|}{ Sikap } \\
\hline Negatif & 72,2 & 27,8 & \multirow[t]{2}{*}{0,005} & 2,05 \\
\hline Positif & 35,5 & 64,7 & & $(1,20-3,50)$ \\
\hline
\end{tabular}

Sumber: Data Primer, 2015 
terhadap HIV mempengaruhi perilaku seksual berisiko penularan HIV di PT. "X" Pelabuhan Kalimas Surabaya. Dengan risiko berperilaku seksual berisiko penularan HIV pada responden yang memiliki sikap negatif 2,05 kali lebih besar dari responden yang memiliki sikap positif.

\section{PEMBAHASAN}

PT. " $X$ " dipilih karena merupakan perusahaan yang memiliki jumlah TKBM sendiri dan jumlah TKBMnya merupakan salah satu yang terbanyak dari perusahaanperusahaan lain yang terdapat di Pelabuhan Kalimas Surabaya, perusahaan ini juga merupakan perusahaan yang paling lama beroperasi di Pelabuhan Kalimas Surabaya.

TKBM di PT. " $X$ " berasal dari berbagai daerah di Jawa Timur, bahkan terdapat TKBM yang berasal dari luar pulau jawa atau dari provinsi lain. Diantaranya ada yang berasal dari Nusa Tenggara Timur dan dari Pulau Kalimantan. Usia TKBM bervariasi mulai dari usia 18 tahun sampai 60 tahun. TKBM yang berasal dari luar Kota Surabaya hanya tinggal di rumah sekitar dua sampai tujuh hari yaitu ketika waktu libur saja. Sedangkan yang di luar pulau hanya pulang satu tahun sekali dan untuk TKBM yang berasal dari dalam Kota Surabaya mereka dapat pulang setiap hari.

TKBM yang tidak pernah pulang atau jarang pulang mereka mayoritas tinggal di sekitar Pelabuhan. Diantaranya di kantin perusahaan, warung-warung, musholla, kapal yang sedang berlabuh di Pelabuhan Kalimas Surabaya dan di dalam gedung perusahaan, tempatnya bekerja. Hanya sedikit TKBM yang tinggal di kos-kosan.

Pendidikan merupakan salah satu usaha pembelajaran untuk meningkatkan serta mengembangkan potensi diri untuk memiliki keterampilan yang diperlukan untuk diri sendiri dan untuk masyarakat. Suatu kegiatan atau usaha pembelajaran dalam rangka pengembangan dan realisasi pencapaian cita-cita dengan tujuan menstransfer pengetahuan. Pendidikan juga suatu proses pengendalian dan manipulasi untuk menyesuaikan dengan orang lain (Nursalam dan Efendi, 2008). Semakin tinggi pendidikan yang dimiliki seseorang maka semakin tinggi persentase untuk mendapatkan informasi tentang kesehatan diataranya HIV dan AIDS (Depkes dan Badan Pusat Statistik, 2007).

Pendidikan terbagi menjadi dua kategori yaitu pendidikan formal dan pendidikan non formal. Pendidikan formal merupakan pendidikan yang berjenjang dimulai dari pendidikan dasar, menengah dan tinggi. Sedangkan pendidikan non formal yaitu pendidikan yang dilakukan di luar pendidikan formal (PPRI No 32, 2013).

Menurut Notoadmodjo (2012), pendidikan memiliki tujuan untuk melawan dan memerangi kebodohan. Pendidikan dapat berpengaruh terhadap meningkatnya kemampuan bekerja dan berusaha sehingga dapat meningkatkan pendapatan. Selanjutnya pendidikan diharapkan dapat meningkatkan kemampuan seseorang untuk mencegah penyakit dan dapat memelihara serta meningkatkan kesehatannya.

Hasil dari penelitian didapatkan mayoritas pendidikan responden berkategori pendidikan rendah. Responden yang termasuk ke dalam kategori ini adalah responden yang tidak pernah sekolah dan hanya sekolah sampai tingkat SD. Hasil ini didukung oleh pernyataan dari Dirjen Pembinaan Hubungan Industri (PHI) dan Jaminan Sosial, Kementerian Tenaga Kerja dan Transmigrasi Ruslan Irianto S. 2013 dalam Paraditya (2013), yang menyatakan bahwa sekitar $70 \%$ buruh yang bekerja masih berstatus lulusan sekolah dasar (SD). Serta menurut Shehadeh dan Virginia (2014), tingkat pendidikan pada buruh migran umumnya tergolong rendah. Namun hasil penelitian ini berbeda dengan penelitian yang dilakukan Mutia (2008), bahwa buruh yang memiliki pendidikan berkategori rendah (SD) sebesar 31\% dan yang berkategori berpendidikan tinggi (SMP dan SMA) berjumlah 69\%.

Berdasarkan hasil uji diperoleh tidak ada hubungan yang signifikan antara tingkat pendidikan responden dengan perilaku seksual berisiko penularan HIV. Hasil ini berbeda dari penelitian yang dilakukan Pratiwi dan Basuki (2011), yang mengatakan bahwa ada hubungan antara tingkat pendidikan dengan perilaku seksual 
tidak aman atau berisiko. Menurut Zambuko dan Mtrui (2005), bahwa tingkat pendidikan berhubungan dengan perilaku seksual dimana responden yang memiliki tingkat pendidikan tinggi berperilaku seksual lebih aman. Seseorang yang berpendidikan tinggi akan mempunyai pengetahuan yang lebih luas dibandingkan dengan seseorang yang tingkat pendidikannya lebih rendah (Notoatmojo, 2007).

Menurut Edberg (2010), salah satu faktor yang sangat berpotensi untuk mempengaruhi perilaku seseorang adalah faktor sosio ekonomi dan struktural. Faktor sosio ekonomi dan struktural yaitu berupa tingkat kesejahteraan, tingkat pendidikan, akses terhadap pelayanan kesehatan.

Pernikahan adalah sebuah ikatan sosial atau merupakan ikatan perjanjian hukum antar pribadi yang membentuk suatu hubungan kekerabatan, dan merupakan suatu pranata budaya setempat yang meresmikan hubungan antar pribadi. Sahnya pernikahan dinyatakan dengan hukum perdata yang berlaku, hukum agama dan peraturan adat kebudayaan yang bersangkutan. Perbedaan cara hidup orang yang berstatus menikah atau yang belum menikah memungkinkan menjadi risiko untuk terkena penyakit tertentu (Noor, 2008).

Menurut Notoadmodjo (2007), status perkawinan memiliki hubungan antara angka kesakitan maupun kematian. Hal ini terjadi karena adanya perbedaan gaya hidup antara yang berstatus menikah dan tidak menikah. Orang yang tidak menikah memiliki angka kematian yang lebih tinggi daripada orang yang menikah. Hal ini dikarenakan ada kecenderungan pada orang yang tidak menikah memiliki gaya hidup kurang sehat.

Status pernikahan menurut Noor (2008), terbagi menjadi empat kategori yang meliputi belum kawin, kawin, janda/duda (cerai mati), dan cerai dengan pasangan yang masih hidup. Status perkawinan dalam penelitian ini dibagi menjadi dua kategori yaitu lajang (belum kawin, cerai baik cerai dengan pasangan yang masih hidup atau tidak) dan menikah. Hasil penelitian didukung dengan hasil STBP tahun 2011, yang menyebutkan terdapat $90 \%$ pekerja Pelabuhan dalam hal ini adalah TKBM dan buruh berstatus menikah.
Berdasarkan hasil uji didapatkan bahwa tidak ada hubungan antara status perkawinan dengan perilaku seksual berisiko penularan HIV. Hasil penelitian ini didukung oleh penelitian yang dilakukan oleh Mutia (2008), bahwa tidak ada hubungan antara status pernikahan dengan perilaku seksual berisiko. Dalam penelitian ini terdapat 50\% responden berstatus menikah melakukan perilaku seksual berisiko penularan HIV. Kecenderungan ini sejalan dengan penelitian yang dilakukan oleh Li dkk (2007), dimana perilaku seksual berisiko terkait HIV dan AIDS pada penduduk cina yang berstatus menikah berhubungan dengan perilaku seksual berisiko. Dan juga penelitian yang dilakukan oleh Shehadeh dan Virginia (2014), menyatakan bahwa status perkawinan pada buruh migran memiliki kecenderungan lebih tinggi untuk berperilaku seksual berisiko. Namun hasil penelitian ini bertentangan dengan penilitian yang dilakukan oleh Pratiwi dan Basuki (2011), bahwa responden yang berstatus belum menikah memiliki perilaku yang lebih berisiko melakukan perilaku seksual berisiko.

Tenaga kerja menurut Paraditya (2013), terbagi menjadi tenaga kerja rohani dan tenaga kerja jasmani. TKBM termasuk ke dalam kategori tenaga kerja jasmani, dikarenakan tenaga kerja ini menggunakan tenaga fisik. Kegiatan bongkar muat dari Pelabuhan meliputi beberapa kegiatan, diantaranya bongkar muat dari kapal ke dermaga/truk atau sebaliknya ke dalam kapal sampai tersusun dalam palka kapal. Pekerjaan ini dilakukan dengan menggunakan alat bantu derek kapal. Pekerjaan ini juga meliputi melepas barang dari dermaga ke dalam gudang atau tempat penumpukan barang atau sebaliknya. Memindahkan barang dari penumpukan barang di gudang maupun lapangan dan menyusun diatas kendaraan atau sebaliknya (Permenhub No. 60, 2014).

Pekerjaan bongkar muat dimulai dari pagi sampai sore hari, namun tidak menutup kemungkinan lembur sampai tengah malam. Hal ini disebabkan karena jadwal pemberangkatan dan kedatangan barang oleh kapal. Sehingga banyak para TKBM hanya memiliki kesempatan yang sedikit 
untuk pulang ke rumah dan berkumpul dengan keluarga. Kondisi yang jauh dari keluarga dan pasangan dalam waktu yang lama dan beban kerja yang dimiliki cukup berat, serta sangat minimnya sarana hiburan yang dapat menghilangkan kepenatan setelah bekerja, dapat memicu kebosanan dan kesepian. Sehingga dapat menimbulkan tekanan pada mental, begitu juga dengan kebutuhan seksual yang tidak terpenuhi. Oleh karena itu frekuensi pulang ke rumah dapat dikaitkan dengan perilaku seksual seseorang. Frekuensi pulang ke rumah yang dimaksudkan dalam penelitian ini adalah seberapa sering responden tersebut pulang ke rumah dalam satu bulannya.

Hasil penelitian didapatkan bahwa responden yang pulang ke rumah $>2$ kali/bulan dan responden yang pulang ke rumah $\leq 2$ kali/bulan memiliki jumlah yang sama besar. Hal ini dikarenakan separuh dari responden berasal dari luar Kota Surabaya di wilayah Jawa Timur, bahkan ada yang berasal dari luar Pulau Jawa seperti Kalimantan dan NTT. Sehingga menyebabkan responden jarang pulang kerumahnya. Sisanya adalah responden yang berasal dari dalam Kota Surabaya dan sebagian daerah Madura. Dengan lokasi yang dekat dengan Pelabuhan Kalimas Surabaya sehingga responden dapat pulang setiap hari.

Berdasarkan hasil uji terdapat hubungan antara frekuensi pulang ke rumah dengan perilaku seksual berisiko penularan HIV. Dengan risiko berperilaku seksual berisiko penularan HIV pada responden yang memiliki frekuensi pulang $\leq 2$ kali perbulan lebih besar dari responden yang frekuensi pulang $>2$ kali per bulan. Hal ini berbeda dengan penelitian yang dilakukan oleh Mutia (2008), bahwa tidak ada hubungan antara frekuensi pulang dengan perilaku seksual berisiko. Namun untuk besar risiko yang dihasilkan sejalan dengan penelitian yang dilakukan, yaitu responden yang memiliki frekuensi pulang lebih lama berisiko lebih besar dibandingkan yang lebih sering pulang. Berdasarkan hasil penelitian yang dilakukannya $12 \%$ buruh setuju dan menganggap wajar jika pria yang jauh dari pasangannya menyalurkan hasrat seksualnya dengan wanita lain.
Perilaku menurut Blum 1974 dalam Notoadmodjo (2012), merupakan faktor terbesar kedua setelah faktor lingkungan yang dapat mempengaruhi kesehatan individu, kelompok maupun masyarakat. Menurut teori ABC (Antecedent, Behavior, Concequence) oleh Sulzer, Azaroff dan Mayer 1997 dalam Notoatmodjo (2010), perilaku seseorang dapat terbentuk dan dihasilkan dari kondisi lingkungan seseorang atau individu tersebut tinggal dan berinteraksi. Perilaku kesehatan pada seseorang tidak hanya dipengaruhi oleh keinginan untuk sehat. Namun bisa terjadi karena adanya tujuan kesehatan yang digabung dengan tujuan lainnya atau hal-hal yang tidak ada kaitannya dengan kesehatan.

Keterpaparan merupakan suatu keadaan seseorang atau individu yang berinteraksi dengan unsur penyebab primer maupun penyebab sekunder yang mendorong terjadinya penyakit. Kondisi yang dapat mempengaruhi kerentanan atau keterpaparan diantaranya yaitu akses kepelayanan kesehatan dan informasi (Arias, 2010). Keterpaparan dalam penelitian disini yang dimaksudkan ialah keterpaparan responden terhadap penyuluhan HIV. Baik yang diperoleh dari tenaga kesehatan, pemerintah maupun pihak swasta.

Peran pendidikan kesehatan dalam perilaku adalah untuk menciptakan perilaku yang kondusif untuk kesehatan. Pendidikan kesehatan berupaya agar masyarakat dapat menyadari dan mengetahui cara memelihara kesehatan, mencegah hal-hal yang dapat merugikan kesehatan dirinya, dan orang lain (Notoatmodjo, 2012).

Berdasarkan hasil penelitian didapatkan bahwa mayoritas responden tidak pernah mendapatkan penyuluhan tentang HIV. Hasil ini didukung dengan penelitian yang dilakukan oleh Mutia (2008) bahwa terdapat $22 \%$ buruh yang pernah mengikuti penyuluhan HIV-AIDS dan $78 \%$ belum pernah mengikuti penyuluhan mengenai HIV dan AIDS.

Sedangkan berdasarkan hasil uji didapatkan tidak ada hubungan antara keterpaparan terhadap penyuluhan HIV dengan perilaku seksual berisiko penularan HIV. Hasil penelitian ini didukung oleh 
penelitian yang dilakukan oleh Mutia (2008), bahwa tidak ada hubungan antara keterpaparan terhadap penyuluhan dengan perilaku seksual berisiko. Namun penelitian ini berbeda dengan penelitian yang dilakukan oleh Yulianingsih (2015), bahwa terdapat hubungan antara keterpaparan informasi dengan perilaku berisiko penularan HIV.

Menurut Aisyah (2015), faktor-faktor yang mempengaruhi perilaku diantaranya adalah emosi, persepsi, motivasi, belajar, dan intelegensia. Belajar adalah suatu bentuk dasar dalam memahami sebuah perilaku karena berkaitan dengan proses kematangan, perkembangan fisik, emosi, motivasi perilaku sosial dan kepribadian. Dalam hal ini penyuluhan merupakan salah satu bentuk pembelajaran.

Pengetahuan ialah suatu hasil pengindraan manusia terhadap sebuah objek dari hasil indra yang dimilikinya. Dipengaruhi oleh intensitas perhatian dan persepsi terhadap suatu objek. Pengetahuan dibagi menjadi enam tingkatan diantaranya adalah tahu, memahami, aplikasi, analisis, sintesis dan evaluasi. Perilaku yang didasarkan pada pengetahuan akan bersifat lebih lama atau melekat pada individu dari pada perilaku yang tidak berdasarkan pada pengetahuan (Notoatmodjo, 2010).

Dari hasil penelitian didapatkan mayoritas responden memiliki pengetahuan yang kurang baik tentang HIV. Hal ini sesuai dengan hasil STBP (2011), pada kelompok pria berisiko didapatkan bahwa kelompok pria pekerja Pelabuhan memiliki pengetahuan yang masih rendah tentang HIV, yaitu sebesar 3\%.

Berdasarkan hasil uji penelitian didapatkan bahwa ada hubungan antara pengetahuan responden tentang HIV dengan perilaku seksual berisiko penularan HIV. Dengan besar risiko berperilaku seksual berisiko penularan HIV pada responden yang berpengetahuan kurang baik lebih besar dari responden yang berpengetahuan baik. Hasil ini sesuai dengan penelitian yang dilakukan oleh Yulianingsih (2015), Bahrami dan Zarani (2015), bahwa terdapat hubungan antara pengetahuan dengan perilaku berisiko penularan HIV. Serta penelitian yang dilakukan Pratiwi dan Basuki (2011), bahwa ada hubungan antara pengetahuan dengan perilaku seksual berisiko. Dengan kecenderungan pada pengetahuan yang rendah berisiko lebih besar berperilaku seksual berisiko dari pada yang memiliki pengetahuan baik.

Perilaku manusia merupakan salah satu faktor yang memiliki peranan penting dalam menentukan status kesehatan individu maupun kesehatan masyarakat (Noor, 2008). Sedangkan menurut Edberg (2010), faktor individu yang berpengaruh dalam perilaku adalah kesadaran dan pengetahuan, karakteristik fisik, sikap dan motivasi, kebiasaan dan tahap perkembangan.

Sikap merupakan suatu reaksi atau respons terhadap sebuah stimulus, rangsangan atau objek. Sikap merupakan kumpulan gejala dalam merespons suatu stimulus atau objek yang melibatkan pikiran, perhatian, pengakuan dan gejala kejiwaan. Memiliki karakteristik kecenderungan untuk berfikir, berpersepsi, dan bertindak, mempunyai motivasi, relatif lebih menetap, dibandingkan emosi dan pikiran serta mengandung beberapa aspek penilaian terhadap objek. Sikap memiliki tiga komponen yaitu kognitif, afektif dan konatif (Notoatmodjo, 2010).

Pengukuran sikap dalam penelitian ini ditentukan dengan menggunakan skala Likert. terbagi menjadi empat kategori yaitu sangat setuju, setuju, tidak setuju, dan sangat tidak setuju. Menggunakan dua tipe pernyataan, pernyataan positif dan pernyataan negatif, untuk responden yang memiliki skor $\mathrm{T} \geq$ mean $\mathrm{T}$ dikategorikan memiliki sikap positif (Azwar S, 2009). Berdasarkan hasil penelitian sebagian besar responden memiliki sikap yang positif terhadap HIV.

Seperti halnya pengetahuan, sikap juga memiliki tingkat berdasarkan intensitasnya. Diantaranya adalah menerima, menanggapi, menghargai dan bertanggung jawab (Notoatmodjo, 2010). Menurut Purwanto 1998 dalam Wawan dan Dewi (2010), sikap positif merupakan suatu kecenderungan tindakan yang menyenangi, mendekati dan mengharapkan objek tertentu. Sedangkan sikap negatif memiliki kecenderungan untuk menjauhi, menghindari, membenci dan tidak menyukai objek tertentu.

Sikap positif terhadap nilai kesehatan tidak selalu terwujud dalam suatu tindakan 
nyata. Hal ini disebabkan oleh beberapa alasan diantaranya tergantung pada situasi saat itu, pengalaman orang lain, berdasarkan banyak dan sedikitnya pengalaman seseorang, dan nilai yang ada dimasyarakat yang menjadi pegangan setiap orang (Notoatmodjo, 2012).

Berdasarkan hasil penelitian terdapat hubungan antara sikap dengan perilaku berisiko penularan HIV dengan risiko berperilaku seksual berisiko penularan HIV. Pada responden yang memiliki sikap negatif memiliki risiko yang lebih besar dari responden yang memiliki sikap positif. Menurut penelitian yang dilakukan Pratiwi dan Basuki (2011) ada hubungan antara sikap dengan perilaku seksual berisiko atau tidak aman. Penelitian ini juga didukung oleh penelitian yang dilakukan Yulianingsih (2015), dan penelitian yang dilakukan oleh Pratiwi dan Basuki (2011), bahwa terdapat hubungan antara sikap dengan perilaku seksual berisiko penularan HIV. Dengan potensi responden yang memiliki sikap negatif berpeluang lebih besar melakukan tindakan berisiko dibandingkan yang memilki sikap positif.

Berdasarkan teori Stimulus Organisme Respon (SOR) oleh Hosland 1953 dalam Notoadmodjo (2007), suatu rangsangan yang diberikan kepada seseorang dapat diterima atau tidak. Jika rangsangan tersebut diterima dan mendapatkan perhatian maka proses selanjutnya adalah timbulnya reaksi perubahan sikap pada seseorang. Akhirnya dilanjutkan dengan adanya reaksi terbuka atau perubahan secara praktik.

Menurut Theory Of Planned Behavior oleh Ajzen 1991 dalam Montano (2008), sikap yang mempengaruhi perilaku dipengaruhi oleh kepercayaan terhadap perilaku dan evaluasi terhadap perilaku. Kepercayaan berperilaku pada penelitian ini adalah kepercayaan bahwa HIV dapat dicegah serta penderita HIV memiliki hak hidup dan sosial yang sama dengan orang yang tidak menderita HIV.

\section{SIMPULAN}

Tidak ada hubungan yang signifikan antara karakteristik pendidikan, status perkawinan, dan keterpaparan terhadap penyuluhan tentang HIV dengan perilaku seksual berisiko penularan HIV di PT. "X" di Pelabuhan Kalimas Surabaya. Terdapat hubungan yang signifikan antara karakteriastik frekuensi pulang ke rumah pada TKBM dengan perilaku seksual berisiko penularan HIV di PT. "X" di Pelabuhan Kalimas Surabaya.

Terdapat hubungan yang signifikan antara pengetahuan dan sikap TKBM dengan perilaku seksual berisiko penularan HIV di PT. "X" di Pelabuhan Kalimas Surabaya.

\section{SARAN}

Kepada pihak pelayanan kesehatan selain meningkatkan peran kesehatan dan pelayanan kesehatan. Serta diharapkan meningkatkan kerjasama dengan berbagai lintas sektor, baik sesama instansi pemerintah dan swasta dalam pencegahan dan penanggulangan HIV.

Diantaranya dengan memberikan penyuluhan dan penyebarluasan informasi tentang HIV sebagai peningkatan pengetahuan responden. Dengan peningkatan pengetahuan diharapkan dapat menimbulkan sikap positif pada responden terhadap HIV. Adapun cara penyampaiannya informasi bisa dengan berbagai metode. Misalnya berupa "Peer Group Councelling" yaitu pendidikan kesehatan yang diberikan oleh sesama teman. Serta penyebaran informasi melalui media pamflet atau spanduk di tempat risiko tinggi.

Peningkatan peran swasta khususnya PT. "X" diharapkan memberikan shift kerja perkelompok tiap minggunya, sehingga responden dapat berkumpul bersama keluarga. Serta diharapkan aktif dalam pencegahan penularan HIV yang ditularkan melalui perilaku seksual berisiko. Memberikan penyuluhan dan memberikan perhatian kesehatan kepada TKBM, dengan pengecekan kesehatan rutin tiap bulan sebagai deteksi dini HIV.

\section{DAFTAR PUSTAKA}

Aisyah, S., 2015. Perkembangan Peserta Didik Dan Bimbingan Belajar. Cetakan Pertama. Yogyakarta: Deepublish. 
Arias, K. M., 2010. Investigasi Dan Pengendalian Wabah Difasilas Pelayan Kesehatan. Jakarta: EGC.

Azwar S, 2009. Sikap Manusiawi Teori Pengukurannya. Yogyakarta: Pustaka Pelajar.

Bahrami, Z. dan Zarani, F., 2015. Appliction of The Information-Moivation and Behavioral Skills (IMB) Model In Risky sexual Behaviors Amongst Male Students. Journal of Infection and Public Health, 8(2), pp. 207-213.

Departemen Kesehatan Dan Badan Pusat Statistik, 2007. Situasi Perilaku Berisiko Dan Prevalensi Di Tanah Papua 2006 Hasil STBP Tahun 2006. Jakarta: Bakti Husada.

Departemen Kesehatan Republik Indonesia (Depkes RI), 2009. Analisis kecenderungan Perilaku Berisiko Terhadap HIV Di Indonesia, Laporan Survei TerpaduBiologi Dan Perilaku Tahun 2007. Jakarta: Bakti Husada

Dinas Kesehatan Provinsi Jawa Timur, 2014. Profil Kesehatan Provinsi Jawa Timur 2013. Dalam: Situasi Derajat Kesehatan. Surabaya: Dinkesprov Jatim, P. 40.

Edberg, M., 2010. Kesehatan Masyarakat Teori Sosial Dan Perilaku. Edisi Pertama. Jakarta: EGC.

Kementerian Kesehatan Direktorat Jendral Pengendalian Penyakit Dan Penyehatan Lingkungan (Dirjen P2PL), 2011. STBP 2011 Survailans Terpadu Biologis Dan Prilaku, Jakarta: Bakti Husada

Kementerian Kesehatan RI, 2014. Informasi Pusat Data Dan Informasi Kesehatan RI, Jakarta Selatan: Pusat Data Dan Informasi.

Li, Xiaoming. Zhang, Liying. Stanton, Bonita. Fang, Xiaoyi. Xiong, Qing. Lin, Danhua, 2007. HIV/AIDS Related Sexual Risk Behaviors Among Rural Residents In China: Potential Role Of Rural-ToUrban Migration. AIDS Education And Prevantion, 19(5), pp. 396-407.

Margawati,K., 2016. Hubungan Karakteristik, Pengetahuan Dan Sikap Tenaga Kerja Bongkar Muat (TKBM) Dengan Perilaku Seksual Berisiko Penularan HIV Di Pelabuhan Kalimas Surabaya. Skripsi. Surabaya: Universitas Airlangga.
Montano, E. Daniel. Danuta, Kasprzyk. Karen, Glanz. Barbara K., Rimer. K, Viswanath., 2008. Theory of Reasoned Action, Theory of Planned Behavior, and The Integrated Behavior Model health Promotion and Health Education. Cetakan ke-4. San Francisco: Jossey Bass.

Mutia A, Y., 2008. Perilaku Seksual Berisiko Terkait HIV-AIDS Pada Buruh Bangunan Di Proyek P PT. Kontruksi. Skripsi. Jakarta: FKMUI.

Noor, N. N., 2008. Epidemiologi. Edisi Revisi. Jakarta: Rineka Cipta.

Notoadmodjo, S., 2007. Kesehatan Masyarakat Ilmu dan Seni. Cetakan Pertama. Jakarta: Rineka Cipta.

Notoatmojo, S., 2007. Promosi Kesehatan Dan Ilmu Prilaku. Jakarta: Rineka Cipta.

Notoatmodjo, S., 2010. Ilmu Perilaku Kesehatan. Cetakan Pertama. Jakarta: Rineka Cipta.

Notoatmodjo, S., 2012. Promosi Kesehatan Dan Perilaku Kesehatan. Jakarta, Rineka Cipta.

Nursalam dan Efendi, F., 2008. Pendidikan Dalam Keperawatan. Cetakan pertama. Jakarta: Salemba Medika.

Penanggulangan Penyakit (P2) Dinas Kesehatan Provinsi Jawa Timur, 2015. Program HIV Di Jawa Timur, Surabaya.

Paraditya, I. I., 2013. Pekerja Di Indonesia Cuma Lulusan Sekolah Dasar. Jakarta: ESIS.

Peraturan Mentri Kesehatan republik Indonesia (Permenkes RI) No 51, 2013. Pedoman Pencegahan Penularan HIV Dari Ibu Ke Anak. Jakarta: Kementerian Kesehatan Republik Indonesia.

Peraturan Mentri Perhubungan (Permenhub) No. 60, 2014. Penyelenggaraan Dan PT. Bongkar Muat Dari Dan Ke Kapal, Jakarta: kementri Perhubungan Republik Indonesia.

Peraturan Pemerintah Republik Indonesia (PPRI) No 32, 2013. Standart Nasional Pendidikan. Jakarta: Presiden

Pratiwi, N. L. dan Basuki, H., 2011. Hubungan Karakteristik Remaja Terkait Risiko Penularan HIV-AIDS Dan Perilaku 
Seks Tidak Aman Di Indonesia. Buletin Penelitian Sistem Kesehatan, 14(4), pp. 346-357.

Shehadeh, N. dan Virginia, H., 2014. Risky Sexual Behaviors: The Role of Ethnic identity in HIV Risk in Migrant Workers. Journal of Association of Nurses in AIDS Care, 25(4), pp. 330-340.

Supranto, J., 2008. Statistik Teori Dan Aplikasi. Edisi Ke-7. Jakarta: Erlangga.

Wawan, A. dan Dewi, 2010. Teori Dan Pengukuran Pengetahuan, Sikap, Dan Perilaku Manusia. Yogyakarta: Nuha Medika

Widoyono, 2011. Penyakit Tropis Epidemiologi, Penularan, Pencegahan
Dan Pemberantasannya. Cetakan Ke-2. Semarang: Erlangga.

Yulianingsih, E., 2015. Faktor-Faktor Yang Berhubungan Dengan Tindakan Berisiko Penularan HIV Pada Siswa SMA Negri Di Kota Gorontalo. JIKMU, 5(2a). pp 311-321.

Yulistiani dan Sumarno, 2013. Farmakoterapi Penyakit

HIV/AIDS. Cetakan Pertama.

Surabaya: Pusat Penerbitan Dan Percetakan Unair (AUP).

Zambuko, O. \& Mturi, A.J., 2005. Sexual Risk Behavior Among The Youth In The Era Of HIV/AIDS In South Africa. Journal Of Biosocial Science, 37(5), pp. 569-584. 